\title{
Assessment of Adaptive Reuse Practices through User Experiences: Traditional Houses in the Walled City of Nicosia
}

\author{
Kağan Günçe ${ }^{1}$ and Damla Misırlısoy ${ }^{2, *}$ \\ 1 Faculty of Architecture, Eastern Mediterranean University, Famagusta, Northern Cyprus, via Mersin 10, \\ Turkey; kagan.gunce@gmail.com \\ 2 Faculty of Architecture, European University of Lefke, Lefke, Northern Cyprus, via Mersin 10, Turkey \\ * Correspondence: dmisirlisoy@eul.edu.tr
}

Received: 20 December 2018; Accepted: 16 January 2019; Published: 21 January 2019

\begin{abstract}
The conservation of traditional residential architecture is crucial in terms of sociocultural continuity. When the traditional houses are no longer used for residential purposes, new functions should be assigned to them for the continuity of the heritage buildings. However, new functions should respect the originality of the heritage building. This research focuses on the conservation and reuse of traditional houses located in the walled city of Nicosia. The walled city is divided into two parts as north and south with a buffer zone between the two. This paper includes case studies of re-functioned traditional houses from the two parts. The study questions the appropriateness of the new functions that have been assigned to the traditional houses both in the northern and southern parts of the city. This research aims to measure and compare the success of the adaptive reuse practices through user experiences. As the method of study, the literature survey was carried out to identify different aspects of adaptive reuse projects. Then, selected buildings were observed through site surveys in order to discover the current condition of the adaptive reuse projects. The third step was to complete the questionnaires with different users in order to question the success of the adaptive reuse projects through the user experience. Finally, the collected data were evaluated and discussed. The respondents were asked to answer questions about each building, which are organized under the three categories of sociocultural, economic, and physical aspects of the heritage buildings. As observed with the evaluated case studies, heritage buildings that are re-functioned with the public use, such as commercial, cultural, and educational use, are more successful in contributing to the sociocultural and economic development of the city. The preservation and reuse of abandoned traditional houses in the walled city contribute to the continuity and livability of the city. For the continuity of the heritage buildings, sociocultural, economic, and physical aspects should be taken into consideration with a holistic approach.
\end{abstract}

Keywords: heritage buildings; walled city of Nicosia; traditional house; adaptive reuse practices; adaptive reuse decision-making; user experience

\section{Introduction}

Heritage buildings are important in transferring the culture for future generations. In time, heritage buildings may lose their original function for various reasons. When they can no longer function with their original function, adaptive reuse may be the only way to preserve their heritage significance.

The reuse and adaptation of buildings have become an increasing trend since increasing the life of a building through reuse can not only lower material, transport and energy consumption, and pollution 
but also provide sustainable environments [1]. Adaptive reuse strategies for heritage buildings provide sustainable developments of built environments [2]. On the other hand, the conservation of architectural heritage ensures economic, cultural, and social benefits to the communities. Today, the role of architectural conservation has changed from preservation to be a part of sustainability [3]. Heritage buildings ensure notice of the past and give character to communities [4].

Adaptive reuse decision-making includes a complex set of considerations, which includes location, heritage, architectural assets, and market trends [3]. The participants in the decision-making should have a clear understanding of how to determine the most appropriate future use for the building. In the decision-making process for heritage buildings, there might be some conflicts between professionals and the public since different actors such as government representatives, architects, architectural historians, developers, and owners often have different ideas regarding the adaptive reuse of heritage buildings [5]. The reuse of heritage buildings with a function that is compatible with their character provides a long-term sustainable option for preservation. It also ensures the proper maintenance of the building and helps to protect the sense of place. Adaptive reuse of heritage buildings is a challenging process since it needs a deeper understanding of heritage values, physical characteristics, and adaptive reuse potentials of the building [6]. The new use and the required changes should protect and enhance the cultural significance of the building.

Sustainability is one of the mostly discussed concepts in recent years that aims to maintain societies and the current resources for further generations. It has different dimensions such as ecological, economic, social, and cultural ones, which interact, complement, and define one another [7-10]. Within the scope of this research, sociocultural sustainability will be discussed, which aims for the conservation of sociocultural values of the related context. Traditional residential architecture reflects the identity, culture, and lifestyle of the related user of the heritage buildings. In this respect, the conservation of traditional residential architecture is crucial in terms of sociocultural continuity [11].

Due to its geographical location and strategic importance, Cyprus was the focus of interest of various cultures and peoples. The island has been under the control of many different powers. In this respect, multicultural identity is one of the most important aspects in the traditional houses of the walled city of Nicosia. The traces of the civilizations that have lived on the island can be seen on the heritage buildings. The most significant characteristics are the different layers on top of each other, which makes the traditional houses of Cyprus unique [12].

The island is divided into two: the northern sector in which Turkish Cypriots live and the southern sector inhabited by Greek Cypriots. The two are separated by a UN buffer zone, which separated the whole island since 1974. Between 1979 and 1985, a bicommunal master plan has been prepared for the city of Nicosia. In the south, the city planning is based on the prepared master plan; however, in the north the master plan is not properly applied.

This study focuses on the reused traditional houses in the walled city of Nicosia that have been converted to different functions. The aim is to question the appropriateness of the new functions assigned to traditional houses through user experience. The study focuses on the selected traditional houses that are located in the northern and southern sector of the walled city. The purpose of the paper is to compare adaptive reuse approaches in the two different parts of the divided walled city through user experience. As the method of the study, questionnaires have been conducted with the users of the traditional houses.

The conservation and adaptive reuse of heritage buildings through social consciousness ensures social and cultural sustainability. Traditional houses that have survived throughout history are informative indicators of the social and cultural lives of societies. Adaptive reuse strategies should be developed to use traditional houses with their original function or functions, which are appropriate to the heritage building. Adaptive reuse should be carried out without harming the architectural identity of the buildings. In adaptive reuse projects, responding to user requirements and to user satisfaction is important in terms of the continuity of the function. 


\section{Methodology}

As the first step of the method, the literature survey was carried out to identify different aspects of adaptive reuse projects. Books, academic journal articles, theses, and proceedings related to the subject were surveyed. Factors that affect the success of adaptive reuse projects were discussed in three groups being sociocultural, economic, and physical aspects of adaptive reuse.

Then, selected buildings were observed through site surveys in order to discover the current condition of the adaptive reuse projects. Twelve traditional houses that have been conserved and reused (six from the northern part and six from the southern part) have been selected according to certain criteria that are indicated below:

- All selected examples are conserved and reused.

- There are style/period variations in the selected traditional houses.

- There are functional variations in terms of the new use of the selected traditional houses.

- All selected examples are unique in terms of their architectural character.

- All selected examples have characteristics of their related period.

The different approaches to the conservation and adaptive reuse of heritage buildings were investigated. The political and economic issues of the island and its relation to the conservation and adaptive reuse of architectural heritage were also discussed.

The third step was to complete the questionnaires with different users in order to question the success of the adaptive reuse projects through the user experience. The number of questionnaires was decided according to the number of users per day. In total, 135 questionnaires were completed: 65 of which were conducted for the buildings in the southern part of Nicosia and 70 in the north. This study also includes a comparative study of the adaptive reuse approaches of traditional houses in the northern and southern part of Nicosia.

Finally, the collected data were evaluated and discussed. The respondents were asked to answer questions about each building, which are organized under the three categories of sociocultural, economic, and physical aspects of the heritage buildings.

\section{Adaptive Reuse Aspects of Heritage Buildings}

Adaptive reuse is not a recent phenomenon; in the past, buildings adapted to new functions. However, these interventions were done without theoretical reflection, and in many cases, heritage preservation was not the main intention. Instead, the main aim of the reuse was functional and financial in nature. In contemporary conservation theory and practice, adaptive reuse is considered a crucial strategy towards the conservation of cultural heritage [13]. The conservation of architectural heritage ensures economic, cultural, and social benefits to the communities. Finding the most appropriate function is crucial in order to preserve the cultural significance of the heritage building. There are many factors that affect the selection of a new use for the heritage buildings in the decision-making process. Therefore, for a sustainable adaptive reuse project, all factors should be taken into consideration in a comprehensive manner [14]. These factors can be categorized under three headings of sociocultural, economic, and physical aspects of adaptive reuse as seen in Table 1. 
Table 1. Aspects in adaptive reuse of heritage buildings (developed according to Reference [12]).

\begin{tabular}{ll}
\hline \multicolumn{1}{c}{ Aspects in Adaptive Reuse } & Relevant Research Study \\
\hline & A1. Awareness of the original function by users \\
A2. Awareness of the building history & A3. Awareness of the building memory \\
A4. Awareness of the new function of the building in the district & [2,15-22] \\
A5. Being a landmark in the region & A6. To meet with the needs of the region \\
A7. Social benefits of the new function for the users & A8. Cultural benefits of the new function for the users \\
A9. To increase the quality of the living conditions in the district & A10. Fitting in the overall image of the neighborhood \\
& B1. Economic benefits of the new function for the users \\
B2. Making a profit with the new function & B3. Economic benefits to the district \\
B4. Contributing to the cultural tourism to the district & B5. Increasing the property value of the district \\
C1. Appropriateness of the new function to the other buildings in \\
the close neighborhood \\
C2. To prevent visual pollution \\
C3. Success of the conservation works \\
C4. Compatibility of the new materials with the heritage building \\
C5. Appropriateness of the new function with the authenticity of \\
the original function \\
C6. Respect to the originality of the building \\
C7. Response to the space requirements of the new function \\
for activities \\
C8. Accessibility of the building for disabled users \\
C9. Accessibility of the building by vehicle \\
C10. Accessibility of the building as pedestrian
\end{tabular}

Social aspects: Investments in adaptive reuse projects may revitalize neglected areas and contribute to an increase in living standards within a local community $[19,23]$. Therefore, this may attract new investments and contribute to economic growth [23]. However, sociocultural aspects also should be taken into consideration.

For a successful adaptive reuse project, the new function of the heritage building should be socio-culturally sustainable. Local people should know the new function of the building, or the building should be a landmark in the region. It should also contribute to the promotion of the area. The original function of the building should be easily understood after the adaptation. The new function should meet the needs of the region, and the building should have social and cultural benefits to users. It should propose new activities for the people. An appropriate function may increase the quality of the living conditions and level of the education in the region.

Economic aspects: The conservation of the architectural heritage can add "value" to an area [19]. Heritage value can be added by keeping the style and character of an architectural heritage, which contributes to providing more attractive places. These factors not only increase the value of the building itself but also increase the value of the properties in the close neighborhood [24].

The new function of the building should have the potential to make a profit in order to provide for the necessary maintenance of the building in the future. A successful adaptation may increase the property values within the area or may contribute to cultural tourism. It is not enough to ensure the physical survival of heritage buildings; they should also be economically sustainable.

Physical aspects: There are physical aspects that should also be emphasized in the decision-making process. Adaptive reuse projects should not be considered in isolation from their surroundings. Each heritage building is a part of the whole so it should be in harmony with the environment and the other functions of the buildings located around it. Abandoned and demolished heritage buildings are not only a loss to the cultural identity of the surrounding area but also create visual pollution. The land 
use of the area should be researched before making decisions, and the needs of the region should be evaluated [12].

Additionally, the new function should be appropriate to the authenticity of the original function. Materials and any additions should be in harmony with the original. Interventions should respect the integrity of the building. The building should address the space requirements of the activities of the new function. In the adaptation process, necessary interventions can damage the originality of the architectural heritage. For a successful adaptive reuse, adaptive reuse aspects should be taken into consideration holistically. Each aspect is an important component of a sustainable heritage adaptation.

\section{The Divided Walled City of Nicosia}

Due to its geographical location and strategic importance, Cyprus was the focus of interest of various cultures and peoples. Being located centrally at the crossroads of European and Middle Eastern civilizations, Cyprus has been under the control of many different powers. These civilizations include the Byzantines (395-1191), the Lusignans (1192-1489), the Venetians (1489-1571), the Ottomans (1571-1878), and the British (1878-1960); however, it is possible to perceive traces of each culture as different styles in the historic monuments of Cyprus [40]. Cyprus remained under the rule of the British until the 1960s. In 1963, intercommunal fights between the Greek and Turkish Cypriots began, and in 1974, Turkey's intervention divided the island into two.

Cyprus is an island that has successfully preserved its rich cultural heritage in spite of the changes in its socioeconomic, economic, and political structure. Even though the changing societal mosaic on the island is not in total conformity with the built environment, traditional architectural traces can still be found. Multicultural identity is one of the most important aspects in the traditional houses of the walled city of Nicosia. The traces of the civilizations that have lived on the island can be seen on the heritage buildings. The most significant characteristics are the different layers on top of each other like a palimpsest. It makes the traditional urban houses of Cyprus unique compared to the traditional architecture of other cultures.

Nicosia is the capital of an island, which has been divided into a Turkish sector in the north and a Greek sector in the south and separated by a UN buffer zone since 1974. The buffer zone cuts through the city of Nicosia and divides the whole island from northwest to southeast (Figure 1). A $180 \mathrm{~km}$ line of demarcation separates the Greek and Turkish Cypriots.

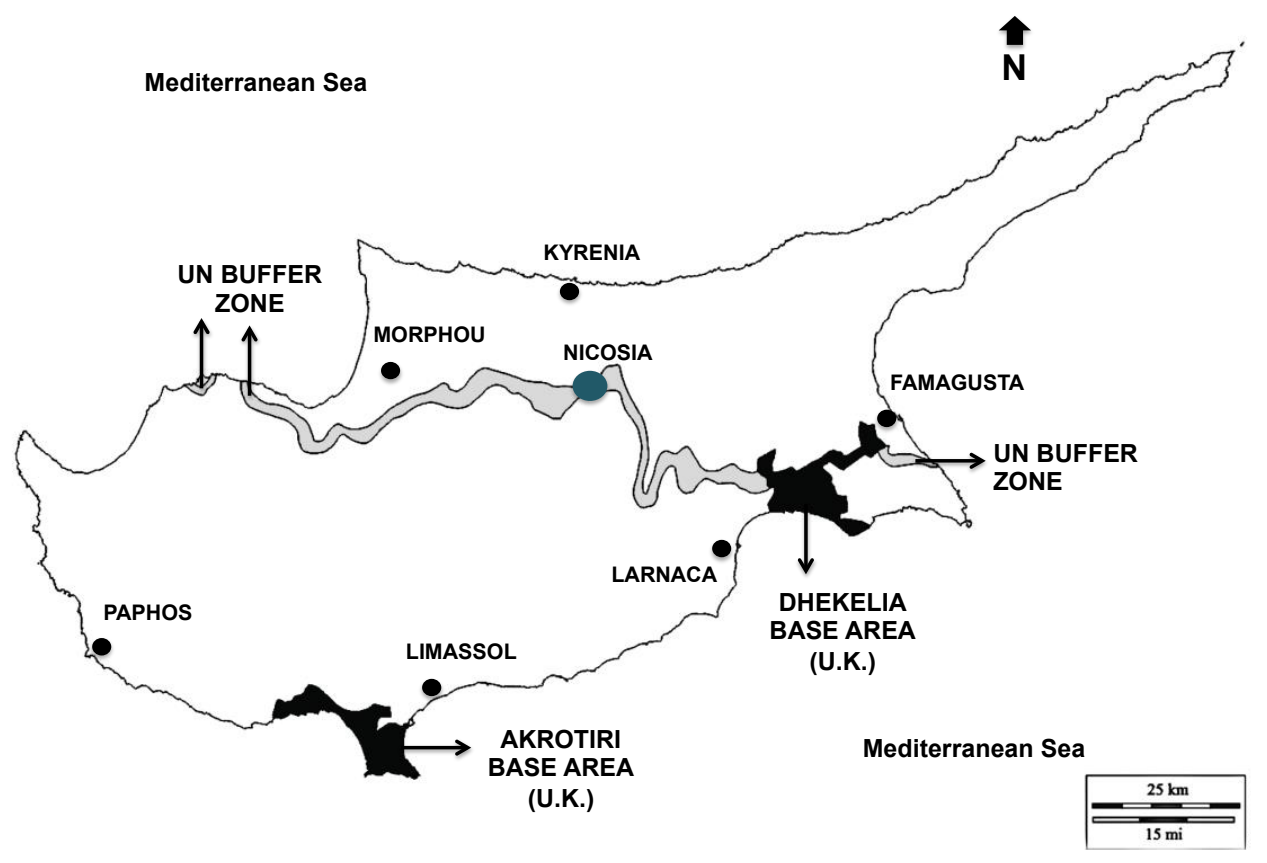

Figure 1. Location of the walled city and the buffer zone. 
Along with the division of the island, the historic walls of Nicosia that surround the historic core of the city are also divided into two parts (Figure 1). It is a city where the traces of history and cultures of many different civilizations can be found so has been the subject of many studies.

The division, which continues today, is the main reason for the city's ongoing problems in terms of restricting development and imposes issues for future planning. In spite of the division, there are efforts on both sides for the revitalization of Nicosia. While the division limits development and creates diverse problems for planning the city, it has created a process of growing out of the old core of Nicosia on both sides which has also caused the neglect of the housing stock and their social value [41].

Four years after the division, the United Nations promoted a common Master Plan for the walled city of Nicosia that aimed for the improvement of the existing human settlement conditions of all the inhabitants of Nicosia and the improvement of the infrastructure of the city. The Nicosia Master Plan team had conducted the research under the control of the EU (United Nations) in order to identify the general problems in the city. The team developed "Policies for the Rehabilitation of the Historic City" after having identified the issues. Then, a series of integrated projects were suggested. Starting from 1986 to the present day, many projects have been conducted with the funds by The United States Agency for International Development (USAID) and the European Union through the United Nations Development Programme (UNDP).

\section{Assessment of Adaptive Reuse of Traditional Houses in the Walled City of Nicosia}

In time, the spaces of heritage buildings cannot meet the needs and aspirations of modern society so they lose their existing functions. With the effect of technological and sociocultural changes, it is not possible to use them in their original function. In order to retain the heritage building, proposing a new function becomes inevitable [42]. However, the challenge is to find the most appropriate function that preserves the significance of the heritage building. In the walled city of Nicosia, while some houses have been renovated and reused, there are still a great number that require an appropriate function. Although most of the buildings have been preserved physically through inappropriate functions, they lack a viable function.

The study questions the appropriateness of the new functions that are assigned to the traditional houses. Twelve case studies (six from the north and six from the south), which are located in the walled city of Nicosia, were selected for this field study. For the selection of these 12 case studies, the classification of the new uses was prepared. There are many classifications regarding the new functions of the reused heritage buildings [43-45]; however, within the framework of this research, new uses of the heritage buildings have been classified as residential, commercial, religious, military, agricultural, governmental, cultural, educational, health, and office [39] as seen in Table 2.

Table 2. Selected case studies from the northern and southern parts of the city according to their new function.

\begin{tabular}{lcc}
\hline Function of the Heritage Building & Northern Part of Nicosia & Southern Part of Nicosia \\
\hline $\begin{array}{l}\text { Residential use } \\
\text { Industrial use }\end{array}$ & M. Mesutoğlu Residence (A1) & S. Angelidou Residence (A2) \\
$\begin{array}{l}\text { Commercial use } \\
\text { Religious use }\end{array}$ & Rüstem Bookshop \& Café (B1) & - \\
Military use & - & Patio Bar (B2) \\
Agricultural use & - & - \\
Governmental use & - & - \\
Cultural use & Yunus Emre Foundation (C1) & Lions Care for Youth Foundation (C2) \\
$\begin{array}{l}\text { Educational use } \\
\text { Health use }\end{array}$ & Eaved House Cultural Center (D1) & Center for Cultural Heritage (D2) \\
Office use & American University of Nicosia (E1) & University of Cyprus (E1) \\
& S\&H Law Firm (F1) & - \\
\end{tabular}

In the walled city of Nicosia, the new uses for the traditional buildings are residential, commercial, governmental, cultural, educational, and office. On the other hand, there are no example of functions 
of industrial, religious, agricultural, and health. There are traditional houses that are located in the buffer zone and used for military purposes. As the selection method of the case studies, two examples (one from the north and one from the south part of Nicosia) were selected for each new function that exists in the walled city. The location of the selected case studies is represented in Figure 2.

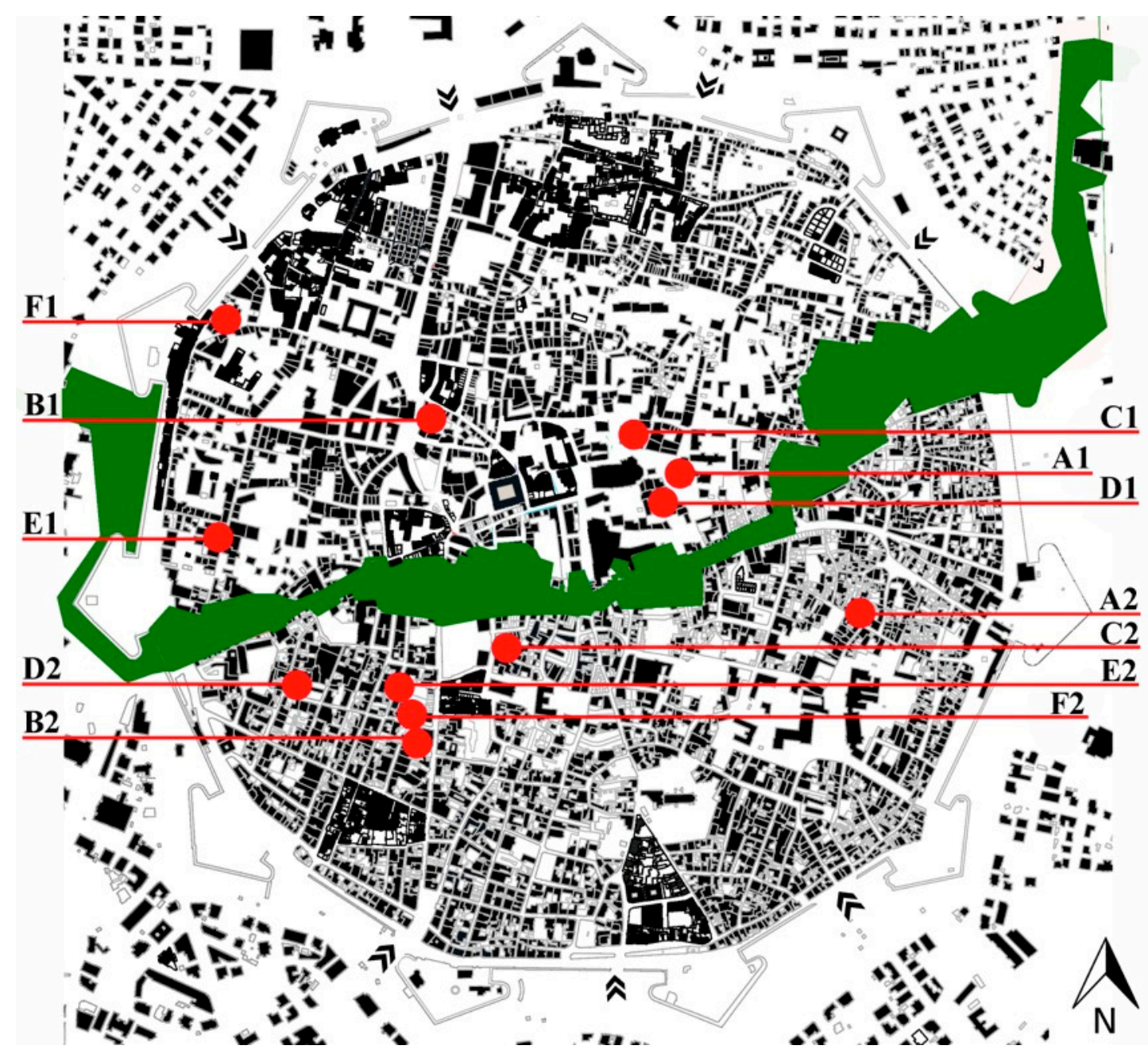

Figure 2. Location of the selected case studies within the walled city of Nicosia (Source: Nicosia Municipality; Redrawn by authors).

Twelve traditional houses that have been conserved and reused (six from the northern part and six from the southern part) have been selected according to certain criteria that are indicated below (Figure 3):

- All selected examples are conserved and reused.

- $\quad$ There are style/period variations in the selected traditional houses.

- There are functional variations in terms of the new use of the selected traditional houses.

- All selected examples are unique in terms of their architectural character.

- All selected examples have characteristics of their related period. 


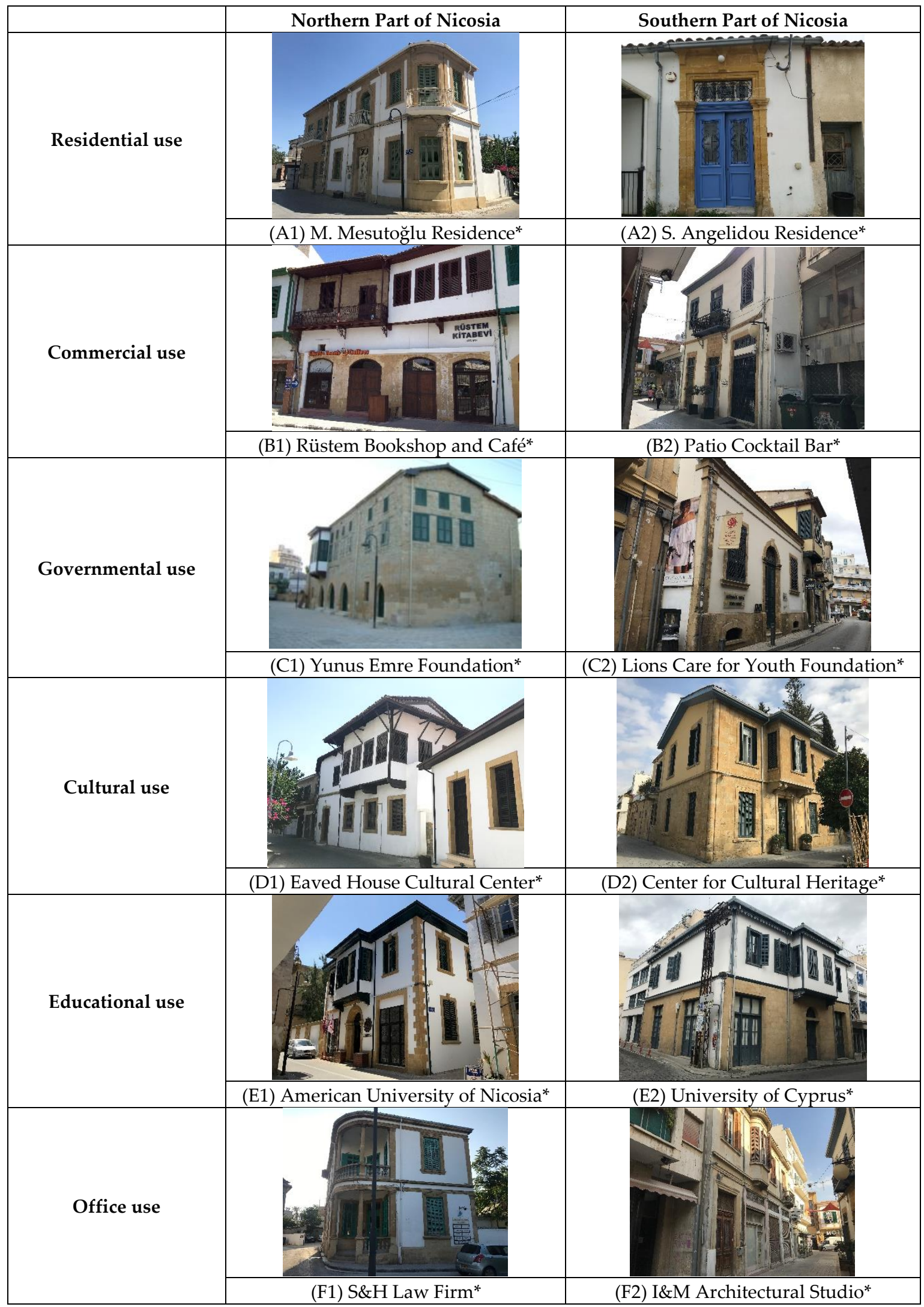

Figure 3. Photos of the selected traditional houses as the case studies ( ${ }^{*}$ Photos taken by the authors in 2018). 


\section{Findings and Discussions}

Twelve traditional houses that are accepted as heritage buildings have been evaluated in terms of the "Sociocultural", "Economic", and "Physical" aspects of adaptive reuse. The evaluation was made through questionnaires with the users of the buildings. The number of questionnaires that were conducted with the users (staff/owner and visitors) of the buildings was decided according to the number of users per day. While the number of visitors of a residential building per day is 5 , the number of visitors of a commercial building can be up to 250. In order to keep the number of questionnaires for each building balanced, the different percentages have been applied as explained in Table 3 .

Table 3. Number of the users and questionnaires for each selected building.

\begin{tabular}{lccc}
\hline \multicolumn{2}{c}{ Name of the Heritage Building } & $\begin{array}{c}\text { Number of Users (Staff/Owner } \\
\text { and Visitors) Per Day }\end{array}$ & Number of the Questionnaire \\
\hline A1 & M. Mesutoğlu Residence & 5 & $5(100 \%)^{*}$ \\
A2 & S. Angelidou Residence & 5 & $5(100 \%)^{*}$ \\
B1 & Rüstem Bookshop and Cafe & 200 & $20(10 \%)^{* * * *}$ \\
B2 & Patio Cocktail Bar & 250 & $25(10 \%)^{* * * *}$ \\
C1 & Yunus Emre Foundation & 100 & $20(20 \%)^{* * *}$ \\
C2 & Lions Care Foundation & 50 & $10(20 \%)^{* * *}$ \\
D1 & Eaved House Cultural Center & 50 & $10(20 \%)^{* * *}$ \\
D2 & Center for Cultural Heritage & 50 & $10(20 \%)^{* * *}$ \\
E1 & American University of Nicosia & 50 & $10(20 \%)^{* * *}$ \\
E2 & University Cyprus & 50 & $10(20 \%)^{* * *}$ \\
F1 & S\&H Law Firm & 25 & $5(20 \%)^{* * *}$ \\
F2 & I\&E Architectural Studio & 10 & $5(50 \%)^{* *}$ \\
\hline
\end{tabular}

Note: * If the number of users is between 0-5 per day, questionnaires have been done with $100 \%$ of the visitors. ${ }^{* *}$ If the number of users is between $6-20$ per day, questionnaires have been done with $50 \%$ of the visitors. ${ }^{* * *}$ If the number of users is between $21-120$ per day, questionnaires have been done with $20 \%$ of the visitors. ${ }^{* * * *}$ If the number of users is between 121-250 per day, questionnaires have been done with $10 \%$ of the visitors.

In total, 135 questionnaires were completed: 65 of which were conducted for the buildings in the southern part of Nicosia and 70 in the north. The results of the questionnaires have been evaluated and the "characteristics of the stakeholders" and the "evaluation of the adaptive reuse aspects" have been represented in Table 4 .

Twelve Traditional houses were selected and questioned under the three main headings as sociocultural, economic, and physical aspects. Ten questions in the sociocultural section, five questions in the economic section, and ten questions in the physical aspects section were directed to the users. The respondents gave answers to the mentioned questions as "yes", "no", or "not sure". Then, the results were evaluated as the percentage and represented in Table 4 under the three main heading as sociocultural, economic, and physical aspects. Finally, at the bottom of the table, the average of each aspect has been calculated.

The results of the questionnaires show that generally, in north, the physical aspects of the heritage buildings have been preserved whereas the sociocultural and economic aspects of the buildings have been neglected in the decision-making process. However, in the southern part, the adaptive reuse of the traditional houses is successful in terms of sociocultural, economic, and physical aspects. 
Table 4. Results of the questionnaires.

\begin{tabular}{|c|c|c|c|c|c|c|c|c|c|c|c|c|c|c|c|}
\hline \multicolumn{16}{|c|}{ Characteristics of the Stakeholders } \\
\hline & \multirow[b]{2}{*}{ Name of the Building } & \multirow[b]{2}{*}{ 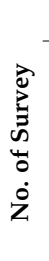 } & \multicolumn{5}{|c|}{ Nationality } & \multicolumn{2}{|c|}{ Sex } & \multicolumn{3}{|c|}{ Age Intervals } & \multicolumn{3}{|c|}{ Education } \\
\hline & & & 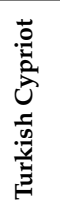 & 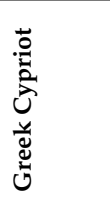 & 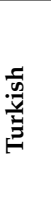 & $\begin{array}{l}\text { ¿ँ } \\
\text { Uँ }\end{array}$ & 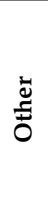 & $\sum_{\Sigma}^{\frac{\pi}{\pi}}$ & 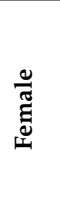 & $\begin{array}{l}\exists \\
\underset{\mid}{0} \\
\stackrel{\infty}{\sim}\end{array}$ & $\begin{array}{l}7 \\
\text { 帛 }\end{array}$ & 苦 & 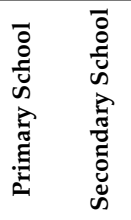 & 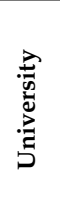 & $\frac{2}{\frac{5}{5}}$ \\
\hline A1 & $\begin{array}{l}\text { M. Mesutoğlu Residence } \\
(\mathrm{NPN})^{*}\end{array}$ & 5 & 5 & - & - & - & - & 3 & 2 & - & 1 & 3 & 3 & 1 & - \\
\hline A2 & $\begin{array}{l}\text { S. Angelidou Residence } \\
\text { (SPN)** }\end{array}$ & 5 & 1 & 3 & - & - & 1 & 1 & 4 & 1 & 1 & 1 & 2 & 2 & 1 \\
\hline B1 & $\begin{array}{l}\text { Rüstem Bookshop and Café } \\
(\text { (NPN)* }\end{array}$ & 20 & 11 & 2 & 3 & - & 4 & 10 & 10 & 6 & 5 & 4 & 5 & 11 & 3 \\
\hline B2 & Patio Cocktail Bar (SPN)** & 25 & 2 & 21 & - & - & 2 & 13 & 12 & 20 & 4 & - & 20 & 2 & 2 \\
\hline $\mathrm{C} 1$ & $\begin{array}{l}\text { Yunus Emre Foundation } \\
\text { (NPN)* }\end{array}$ & 20 & 13 & 1 & 4 & - & 2 & 12 & 8 & 10 & 3 & 2 & 4 & 11 & 3 \\
\hline $\mathrm{C} 2$ & $\begin{array}{l}\text { Lions Care Foundation } \\
(\mathrm{SPN})^{* *}\end{array}$ & 10 & 1 & 7 & - & 1 & 1 & 5 & 5 & 6 & 1 & 1 & 5 & 3 & 1 \\
\hline D1 & $\begin{array}{l}\text { Eaved House Cultural } \\
\text { Center (NPN)* }\end{array}$ & 10 & 6 & 1 & 1 & - & 2 & 6 & 4 & 3 & 2 & 2 & 1 & 6 & 2 \\
\hline D2 & $\begin{array}{l}\text { Center for Cultural Heritage } \\
\text { (SPN)** }\end{array}$ & 10 & 1 & 6 & - & - & 3 & 3 & 7 & 1 & 4 & 3 & 3 & 4 & 2 \\
\hline E1 & $\begin{array}{l}\text { American University of } \\
\text { Nicosia (NPN)* }\end{array}$ & 10 & 5 & - & 3 & - & 2 & 4 & 6 & 5 & 1 & 2 & 5 & 2 & 2 \\
\hline E2 & University Cyprus (SPN)** & 10 & 1 & 6 & - & 1 & 2 & 6 & 4 & 7 & 1 & 1 & 8 & 1 & 1 \\
\hline F1 & S \& H Law Firm (NPN)* & 5 & 3 & - & 1 & - & 1 & 4 & 1 & 1 & 3 & - & 2 & 2 & - \\
\hline $\mathrm{F} 2$ & $\begin{array}{l}\text { I \& E Architectural Studio } \\
\text { (SPN)** }\end{array}$ & 5 & - & 4 & - & - & 1 & 3 & 2 & 1 & 1 & 1 & 2 & 2 & 1 \\
\hline \multicolumn{16}{|c|}{ Evaluation Adaptive Reuse Aspects } \\
\hline & & \multicolumn{5}{|c|}{ Sociocultural Aspects } & & \multicolumn{4}{|c|}{ Economic Aspects } & \multicolumn{4}{|c|}{ Physical Aspects } \\
\hline & & & Yes & No & & Tot Sure & & Yes & & No & $\begin{array}{l}\text { Not } \\
\text { Sure }\end{array}$ & Yes & No & & $\begin{array}{l}\text { Not } \\
\text { Sure }\end{array}$ \\
\hline A1 & $\begin{array}{l}\text { M. Mesutoğlu Residence } \\
(\text { (NPN)* }\end{array}$ & & $36 \%$ & $62 \%$ & & $2 \%$ & & $36 \%$ & & $60 \%$ & $4 \%$ & $90 \%$ & $8 \%$ & & $2 \%$ \\
\hline A2 & $\begin{array}{l}\text { S. Angelidou Residence } \\
\text { (SPN)** }\end{array}$ & & $32 \%$ & $60 \%$ & & $8 \%$ & & $8 \%$ & & $88 \%$ & $4 \%$ & $94 \%$ & $4 \%$ & & $2 \%$ \\
\hline B1 & $\begin{array}{l}\text { Rüstem Bookshop and Café } \\
(\text { (NPN)* }\end{array}$ & & $90 \%$ & $6 \%$ & & $4 \%$ & & $93 \%$ & & $3 \%$ & $4 \%$ & $86 \%$ & $11 \%$ & & $3 \%$ \\
\hline B2 & Patio Cocktail Bar $(\mathrm{SPN})^{* *}$ & & $66 \%$ & $28 \%$ & & $6 \%$ & & $88 \%$ & & $4 \%$ & $8 \%$ & $84 \%$ & $14 \%$ & & $2 \%$ \\
\hline $\mathrm{C} 1$ & $\begin{array}{l}\text { Yunus Emre Foundation } \\
\text { (NPN)* }\end{array}$ & & $95 \%$ & $0 \%$ & & $5 \%$ & & $35 \%$ & & $60 \%$ & $5 \%$ & $80 \%$ & $20 \%$ & & $0 \%$ \\
\hline $\mathrm{C} 2$ & $\begin{array}{l}\text { Lions Care Foundation } \\
(\mathrm{SPN})^{* *}\end{array}$ & & $90 \%$ & $5 \%$ & & $5 \%$ & & $35 \%$ & & $65 \%$ & $0 \%$ & $79 \%$ & $19 \%$ & & $2 \%$ \\
\hline D1 & $\begin{array}{l}\text { Eaved House Cultural } \\
\text { Center (NPN)* }\end{array}$ & & $88 \%$ & $5 \%$ & & $7 \%$ & & $86 \%$ & & $12 \%$ & $2 \%$ & $81 \%$ & $17 \%$ & & $2 \%$ \\
\hline D2 & $\begin{array}{l}\text { Center for Cultural Heritage } \\
\text { (SPN)** }\end{array}$ & & $98 \%$ & $0 \%$ & & $2 \%$ & & $10 \%$ & & $70 \%$ & $20 \%$ & $96 \%$ & $4 \%$ & & $0 \%$ \\
\hline E1 & $\begin{array}{l}\text { American University of } \\
\text { Nicosia (NPN)* }\end{array}$ & & $92 \%$ & $4 \%$ & & $4 \%$ & & $92 \%$ & & $8 \%$ & $0 \%$ & $56 \%$ & $40 \%$ & & $4 \%$ \\
\hline E2 & University Cyprus (SPN)** & & $85 \%$ & $8 \%$ & & $7 \%$ & & $82 \%$ & & $14 \%$ & $4 \%$ & $67 \%$ & $28 \%$ & & $5 \%$ \\
\hline F1 & S \& H Law Firm $(\mathrm{NPN})^{*}$ & & $38 \%$ & $52 \%$ & & $10 \%$ & & $88 \%$ & & $8 \%$ & $4 \%$ & $40 \%$ & $58 \%$ & & $2 \%$ \\
\hline $\mathrm{F} 2$ & $\begin{array}{l}\text { I \& E Architectural Studio } \\
(\text { (SPN)** }\end{array}$ & & $42 \%$ & $46 \%$ & & $12 \%$ & & $88 \%$ & & $12 \%$ & $0 \%$ & $42 \%$ & $56 \%$ & & $2 \%$ \\
\hline & AVERAGE & & $71 \%$ & $23 \%$ & & $6 \%$ & & $62 \%$ & & $34 \%$ & $4 \%$ & $75 \%$ & $23 \%$ & & $2 \%$ \\
\hline
\end{tabular}

Note: If the percentage is over $50 \%$, the heritage building is accepted as successful in terms of the mentioned aspect. ${ }^{*}(\mathrm{NPN})$ Northern part of Nicosia; **(SPN) Southern part of Nicosia. 
Re-functioned traditional houses have been grouped according to their new uses and named as $\mathrm{A} 1, \mathrm{~A} 2, \mathrm{~B} 1, \mathrm{~B} 2, \mathrm{C} 1, \mathrm{C} 2, \mathrm{D} 1, \mathrm{D} 2, \mathrm{E} 1, \mathrm{E} 2, \mathrm{~F} 1$, and F2 as seen in Table 4. If the percentage is more than $50 \%$, in general, the building is accepted as successful in terms of the mentioned aspects. Accordingly, buildings B1, B2, D1, D2, E1, and E2 are the most successful case studies since they are successful in terms of all aspects of adaptive reuse (sociocultural, economic, and physical). B1, B2, C1, C2, D1, D2, E1, and E2 are successful in terms of economic aspects. On the other hand, B1, B2, D1, E1, E2, F1, and F2 are successful in terms of physical aspects. Lastly, all of the buildings are successful in terms of physical aspects except F1 and F2. The findings are discussed as follows:

- $\quad$ A1 and A2, M. Mesutoğlu Residence and S. Angelidou Residence, which are used for residential purposes were found unsuccessful in terms of sociocultural and economic aspects. However, they are successful in terms of their physical aspects. Reusing traditional houses as the original function ensures sociocultural sustainability; however, since the aim does not have profits, the economic sustainability of the heritage building may not be ensured.

- B1 and B2, Rüstem Bookshop and Café and Patio Cocktail Bar which have been converted to commercial use, have been found to be successful in terms of sociocultural, economic, and physical aspects. It has been indicated by the respondents that the heritage buildings that are re-functioned as commercial use (public use) have benefits to the users in terms of sociocultural, economic, and physical aspects. The heritage building has been re-functioned with an appropriate function, and it is in harmony with the context.

- $\quad$ C1 and C2, Yunus Emre Foundation and Lions Care for Youth Foundation are now used with governmental uses as foundation buildings. Both heritage buildings have been found successful in terms of sociocultural and physical aspects; however, they are unsuccessful in terms of economic aspects. Since the buildings with the governmental purpose do not aim to have profits, they have been found as unsuccessful in terms of economic aspects. On the other hand, they are socioculturally and physically successful, since they are partially in harmony with the existing context and appropriately re-functioned.

- D1 and D2, Eaved House Cultural Center and Center for Cultural Heritage have been converted to cultural uses. While the Eaved House Cultural Center has been found successful in terms of sociocultural, economic, and physical aspects, the Center for Cultural Heritage is successful in terms of sociocultural and physical aspects but is unsuccessful in terms of economic aspects. Eaved House is a multifunctional center, which can be rented to organize different activities in the center. In this respect, while they both could make profits from the organized events to be used for future maintenance of the heritage buildings, the Center for Cultural Heritage does not aim to have profits.

- $\quad$ E1 and E2, American University of Nicosia and University of Cyprus have been converted to educational uses. Both of the buildings, which are in use as university buildings, have been found successful in terms of sociocultural, economic, and physical aspects. It has been indicated by the respondents that the heritage buildings that are re-functioned as educational use (public use) have benefits to the users in terms of sociocultural, economic, and physical aspects. The heritage building has been re-functioned with an appropriate function, and it is in harmony with the context.

- F1 and F2, S\&H Law Firm and I\&M Architectural Studio which are in use as office buildings, have been found unsuccessful in terms of sociocultural and physical aspects; however, they are successful in terms of economic aspects. As indicated by the respondents, since the heritage buildings have been re-functioned in terms of economic purposes, the sociocultural and physical aspects of the heritage buildings have been ignored.

When the selected heritage buildings have been evaluated within their context, it can be said that they are successful in terms of sociocultural, economic, and physical aspects. There is the functional 
variation of the proposed new functions. Multipurpose use of the heritage buildings may have various benefits for the users and the local community.

According to the results, it is estimated that in order to sustain a heritage building, sociocultural, economic, and physical aspects of adaptive reuse should be taken into consideration holistically. It is not enough to preserve only the physical aspects of the heritage building. It is also important to sustain its economic and sociocultural values. The selected examples, in which sociocultural and economic aspects have not been sustained, have been preserved as cultural heritage assets, but they lack a living function.

\section{Conclusions}

After 1974, when the division took place, residents of the walled city of Nicosia in the northern and southern parts started to leave the city due to social, cultural, economic, and political issues. In the walled city of Nicosia, the majority of the building stock is traditional houses that are worth preserving for their cultural heritage. After UNDP started to work actively on various conservation works of the heritage buildings in the walled city of Nicosia, a transformation of the city has begun. The local community has started to invest in and renovate heritage buildings.

The traditional houses in the walled city need to be conserved and reused as different functions since most of them lost their function as residential purposes. Using traditional houses with different purposes will propose various benefits and opportunities to the local community and tourists. As observed with the evaluated case studies, heritage buildings that are re-functioned with the public use, such as commercial, cultural, and educational use, are more successful in contributing to the sociocultural and economic development of the city.

The walled city of Nicosia is rich in terms of architectural heritage; however, it is observed that due to the lack of awareness in the conservation of heritage buildings and economic conditions, only a few traditional houses have been preserved and reused. The traditional way of life should be transmitted to further generations in order to ensure the sociocultural sustainability.

In order to preserve the heritage buildings and transfer them to future generations, adaptive reuse is inevitable. Preserving and reusing abandoned traditional houses in the walled city will contribute to the socio-sustainability, continuity, and livability of the city. For the continuity of the heritage buildings, the sociocultural, economic, and physical aspects should be taken into consideration with a holistic approach.

The conservation and adaptive reuse of heritage buildings through social consciousness ensures social and cultural sustainability. Traditional houses that have survived throughout history are informative indicators of the social and cultural lives of societies. Adaptive reuse strategies should be developed to use traditional houses with their original functions or appropriate functions with the authenticity of the original function. Adaptive reuse should be carried out without harming the architectural identity of the buildings. In adaptive reuse projects, responding to user requirements and to user satisfaction is important in terms of the continuity of the function.

Policies towards increasing social awareness should be developed. In both parts of the walled city, studies on documentation and evaluation of the architectural heritage should be carried out and restoration projects should be developed.

Author Contributions: Conceptualization, K.G. and D.M.; Methodology, K.G. and D.M.; Software, K.G. and D.M.; Validation, K.G. and D.M.; Formal Analysis, K.G. and D.M.; Investigation, K.G. and D.M.; Resources, K.G. and D.M.; Data Curation, K.G. and D.M.; Writing-Original Draft Preparation, K.G. and D.M.; Writing-Review \& Editing, K.G. and D.M.; Visualization, K.G. and D.M.; Supervision, K.G. and D.M.; Project Administration, K.G. and D.M.; Funding Acquisition, K.G. and D.M.

Funding: This research received no external funding.

Acknowledgments: Authors would like to thank Ziya Moustafa and Tevfik Buğrahan for their contribution in the language editing of the article.

Conflicts of Interest: The authors declare no conflict of interest. 


\section{References}

1. Bullen, P.A.; Love, P.E.D. Residential regeneration and adaptive reuse: Learning from the experiences of Los Angeles. Struct. Surv. 2009, 27, 351-360. [CrossRef]

2. Conejos, S.; Langston, C.; Smith, J. AdaptSTAR model: A climate-friendly strategy to promote built environment sustainability. Habitat Int. 2012, 37, 95-103. [CrossRef]

3. Bullen, P.A.; Love, P.E.D. Adaptive reuse of heritage buildings. Struct. Surv. 2011, 29, 411-421. [CrossRef]

4. Department of the Environment and Heritage (DEH). Adaptive Reuse: Preserving Our Past, Building Our Future; Department of Environment and Heritage, Commonwealth of Australia: Parkes, ACT, USA, 2004; p. 17.

5. Yildırım, M. Assessment of the decision-making process for re-use of a historical asset: The example of Diyarbakir Hasan Pasha Khan, Turkey. J. Cult. Herit. 2012, 13, 379-388. [CrossRef]

6. Günçe, K.; Mısırlısoy, D. Adaptive Reuse of Military Establishments as Museum: Conservation vs. Museography; WIT Transactions on Ecology and the Environment; WIT Press: London, UK, 2014; Volume 143, ISSN 1743-3509.

7. Scott, A. Dimensions of Sustainability; Taylor and Francis: London, UK, 1998.

8. Polese, M.; Stren, R. The Social Sustainability of Cities: Diversity and the Management of Change; University of Toronto Press: London, UK, 2000.

9. Throsby, D. Tourism, heritage and cultural sustainability: Three 'golden rules'. In Cultural Tourism and Sustainable Local Development; Girard, L.F., Nijkamp, P., Eds.; Ashgate: Aldershot, UK, 2009; pp. 13-29.

10. Murzyn-Kupisz, M. Cultural, economic and social sustainability of heritage tourism: Issues and challenges. Econ. Environ. Stud. 2012, 12, 113-133.

11. Chiu, R.L. Socio-cultural Sustainability of Housing: A Conceptual Exploration. Taylor Francis Hous. Theory Soc. 2004, 21, 65-76. [CrossRef]

12. Misırlısoy, D.; Günçe, K. A critical look to the adaptive reuse of traditional urban houses in the Walled City of Nicosia. J. Archit. Conserv. 2016, 22, 149-166. [CrossRef]

13. Plevoets, B.; Cleempoel, K.V. Adaptive reuse as a strategy towards conservation of cultural heritage: A survey of 19th and 20th century theories. In Proceedings of the IE International Conference: Reinventing Architecture and Interiors: The Past, The Present and The Future, London, UK, 28-29 March 2012.

14. Mısırlısoy, D.; Günçe, K. Adaptive reuse strategies for heritage buildings: A holistic approach. Sustain. Cities Soc. 2016, 26, 91-98. [CrossRef]

15. Aydın, D.; Okuyucu, E. Yeniden kullanıma adaptasyon ve sosyo-kültürel sürdürülebilirlik bağlamında Afyonkarahisar Millet Hamamının değerlendirilmesi (Assessment of Afyonkarahisar Millet Hammam in the context of adaptive reuse and socio-cultural sustainability). Megaron 2009, 4, 35-44.

16. Bullen, P.A. Adaptive reuse and sustainability of commercial buildings. Facilities 2007, 25, 20-31. [CrossRef]

17. Fuentes, J.M. Methodological bases for documenting and reusing vernacular farm architecture. J. Cult. Herit. 2010, 11, 119-129. [CrossRef]

18. Dyson, K.; Matthews, J.; Love, P. Critical success factors of adapting heritage buildings: An exploratory study. Built Environ. Proj. Asset Manag. 2016, 6, 44-57. [CrossRef]

19. Langston, C.; Wong, F.K.W.; Hui, E.C.M.; Shen, L. Strategic assessment of building adaptive reuse opportunities in Hong Kong. Build. Environ. 2008, 43, 1709-1718. [CrossRef]

20. Wang, H.J.; Zeng, Z.T. A multi-objective decision making process for reuse selection of historic buildings. Expert Syst. Appl. 2010, 37, 1241-1249. [CrossRef]

21. English Heritage. Conservation Principles, Policies and Guidance for the Sustainable Management of the Historic Environment; English Heritage Discussion Document; English Heritage: London, UK, 2008.

22. Feilden, B.M.; Jokilehto, J. Management Guidelines for World Heritage Sites; ICCROM: Rome, Italy, 1998.

23. Ball, R. Developers, regeneration and sustainability issues in the reuse of vacant buildings. Build. Res. Inf. 1999, 27, 140-148. [CrossRef]

24. Bullen, P.A.; Love, P.E.D. Factors influencing the adaptive re-use of buildings. J. Eng. Des. Technol. 2011, 9, 32-46. [CrossRef]

25. Kincaid, D. Adapting Buildings for Changing Uses: Guidelines for Change of Use Refurbishment; Taylor and Francis: London, UK, 2002.

26. Langston, C.; Shen, L.Y. Application of the Adaptive reuse application model in Hong Kong: A case study of Lui Seng Chun. Int. J. Strateg. Prop. Manag. 2007, 11, 193-207. [CrossRef] 
27. Nasser, N. Planning for urban heritage places: Reconciling conservation. tourism, and sustainable development. J. Plan. Lit. 2003, 17, 467-479. [CrossRef]

28. Shipley, R.; Utz, S.; Parsons, M. Does adaptive reuse pay? A study of the businesses of building renovation I Ontario. Canada. Int. J. Herit. Stud. 2006, 12, 505-520. [CrossRef]

29. Wilkinson, S.; Reed, R.; Kimberley, J. Using building adaptive reuse to deliver sustainability in Australia. Struct. Surv. 2009, 27, 46-61. [CrossRef]

30. Worthing, D.; Bond, S. Managing Built Heritage the Role of Cultural Significance; Blackwell Publishing: Oxford, UK, 2008.

31. Yung, E.H.K.; Chan, E.H.W. Implementation challenges to the adaptive reuse of heritage buildings: Towards the goals of sustainable, low carbon cities. Habitat Int. 2012, 36, 352-361. [CrossRef]

32. ICOMOS. Venice Charter, International Charter for the Conservation and Restoration of Monuments and Sites. 1964. Available online: http:/ / www.icomos.org (accessed on 20 January 2018).

33. ICOMOS. Resolutions of the Symposium on the Introduction of Contemporary Architecture into Ancient Groups of Buildings. 1972. Available online: http:/ / www.icomos.org (accessed on 20 January 2018).

34. ICOMOS. Burra Charter, The Charter for Places of Cultural Significance. 1999. Available online: http: / / australia.icomos.org (accessed on 20 January 2018).

35. UNESCO. Recommendation Concerning the Safeguarding and Contemporary Role of Historic Areas. 1976. Available online: http:/ / www.unesco.org (accessed on 20 January 2018).

36. UNESCO. Vienna Momerandum on World Heritage and Contemporary Architecture-Managing the Historic Urban Landscape. 2003. Available online: http:/ / www.unesco.org (accessed on 20 January 2018).

37. UNESCO. Convention for Safeguarding of the Intangible Cultural Heritage, Paris. 2003. Available online: http:/ / www.unesco.org (accessed on 20 January 2018).

38. English Heritage. Sustaining the Historic Environment: New Perspectives on the Future; English Heritage: London, UK, 1997.

39. Misırlısoy, D. A Holistic Model for Adaptive Reuse Strategies of Heritage Buildings. Ph.D. Thesis, Eastern Mediterranean University, Famagusta, Cyprus, 2016.

40. Jeffrey, G. A Description of the Historic Monuments of Cyprus; Zeno Publisher: London, UK, 1983.

41. Oktay, D. An analysis and review of the Divided City of Nicosia, Cyprus and new perspectives. Geography 2007, 92, 231-247.

42. Günçe, K.; Misırlısoy, D. Questioning the adaptive reuse of industrial heritage and its interventions in the context of sustainability. Sociology Study 2015, 5, 718-727.

43. Cantacuzino, S. New Uses for Old Buildings; Architectural Press: London, UK, 1975.

44. Douglas, J. Building Adaptation; Butterworth-Heinemann Publishing: London, UK, 2002.

45. Latham, D. Creative Re-Use of Buildings: Volume IEII; Routledge: London, UK, 2000. 